\title{
Malay Landscape: Typical design for contemporary house at Desa Wawasan
}

\author{
Nur Huzeima Mohd Hussain, Suriati Ahmad \\ Faculty of Architecture, Planning \& Surveying, \\ Universiti Teknologi MARA, Perak, Malaysia \\ nurhu154@perak.uitm.edu.my
}

\begin{abstract}
The landscape agenda as looking at the global contact nowadays is gaining its popularity and dominates the need and importance of a good surrounding. In peeling the dilemma of the Malay contemporary community, a study has been conducted in conjunction with identifying the needs and their favouritism in accordance to the need and current lifestyle. Desa Wawasan reflect to villages that adapt Gerakan Daya Wawasan (GDW) has been chosen specifically in order to see the efficiency and effectiveness of systematic planning and maintenance held by it's society regard to their surrounding. This research impose a qualitative approach. The collected information is based on the secondary data, field study such as on site observation, interview and questionnaire to the selected respondent based on the study sample. Based on the research conducted, the study has discover the design characteristics with the usage of typical element at Desa Wawasan residential which have been identically more systematic and comprehensive. Hence, the effectiveness of GDW concept can be considered as module as it can be highlighted as one of the sentiment that contribute in creating image and identity of Malay contemporary landscape.
\end{abstract}

Keywords: Malay landscape, contemporary community, systematic planning, maintenance.

eISSN 2514-751X @ 2017 The Authors. Published for AMER ABRA by e-International Publishing House, Ltd., UK.. This is an open access article under the CC BY-NC-ND license (http://creativecommons.org/licenses/by-ncnd/4.0/). Peer-review under responsibility of AMER (Association of Malaysian Environment-Behaviour Researchers), ABRA (Association of Behavioural Researchers on Asians) and cE-Bs (Centre for EnvironmentBehaviour Studies), Faculty of Architecture, Planning \& Surveying, Universiti Teknologi MARA, Malaysia.

https://doi.org/10.21834/aje-bs.v2i2.180 


\subsection{Introduction}

The importance of landscape nowadays is not only to be considered as a satisfaction but its function has spread as one of the basic needs in our daily life. Currently, landscape design is seen to become as one of the main contributor towards marketing strategy and at the same time it injects the interested buyer with good promotions. Provided, how far demand on the design can influence the mind and taste of society. Is scattered compound tradition still synonym to the landscape contemporary polar? How does culture and civilization give impact on the current Malay society lifestyle? Changes of modernisation and urbanization is of vigorous strides. Various aspects and new elements have been discoursed with regards to Malay contemporary. The community seems to be colonized. Is the thinking or mentality of society also shifted?

Hence, the problem approach that is synonym to contemporary landscape of local society will be the main focus in order to see the effectiveness of development in the rural community and Malaysia people as a whole. This study has selected Desa Wawasan as a medium of performance indicators for landscape design of the Malay contemporary house, whether the current needs with traditional civilization still remains in line or otherwise. In peeling the next question, this will lead to the community of Desa Wawasan whereby Gerakan Desa Wawasan will be the rural development philosophy and strategy in the year 2020 by the Ministry of Rural Development through its second core transformation. Gerakan Desa Wawasan is a structured effort that was planned to change the attitude of the rural society and their traditional agriculture culture to commercial and industrial agricultural practises.

Towards achieving this goal, the rural development strategy that focuses on the agriculture sector, preparation of basic facilities and infrastructure (example of construction of road, electricity, and other basic utilities) that has been carried out since the country gained its independence should be changed according to the conditions and environment that has changed in order to achieve the national aspirations of Vision 2020. Besides, the present study also touches on the issue, influence and impact on landscape design in a residential landscape of contemporary Malay.

\subsection{Literature Review}

\subsection{Theoretical approach}

A theoretical framework can be used as a guide or reference to facilitate the understanding of the early construction of the concepts involved in the early stages of research. The theory put forward approach is related to the understanding of perception. Hence, the theory of the approach is considered to be a guide in measuring or interpreting an understanding of the nature of subjective and universal. 
The Theoretical framework that is considered appropriate to be applied in this study touches on the project summary Zube et al. (1982) which continued the work in the psychology of learning environments by W.H Ittelson of building a theoretical framework of landscape perception that is practical and rational. Some things to consider for use in the research landscape in general effects is the inter-relationship between human interaction and landscape. This will then touch on the needs and requirements that exist and practice between the two instruments and associating with the landscape design requirement of the Malay contemporary house.

Among other things, the theory of Zube et al. (1982) also touched on the conclusions drawn by Ittelson about perception. First, the perception is free from direct stimulus control. Second, the perception cannot be separated and cannot be identified from other aspects of psychological and third, the perception is accurate and suitable to the environment context that it is triggered.

\subsection{Traditional Malay house environment}

The concept of the interior architecture of traditional Malay house is tolerant to the external spaces or traditional Malay house compound. Landscape surrounding the house reflects the simplicity of the traditional Malay society based on their beliefs and philosophy (Ismail NA and Said I, 2002). Thus, the surrounding of the Malay traditional house also relates to its internal activities. Essentially, all elements have interest and function, other than a way of life and taboos that play a role in the placement of landscape elements in the house surrounding of traditional Malay society (Maliki NZ, 2008). In general, landscape development in traditional Malay society is to achieve harmony with the environment.

\subsubsection{Front compound}

The front yard is located in front of the house compound and is known by its wide space and aesthetic elements. At this front yard, children can play with happiness and comfort. This space is free from the vehicles and only pedestrians (the villagers) are allowed to pass. This compound is also often being used to entertain guests during feasts, example like a wedding ceremony, circumcision, reading the Quran, and others. It is a space that reflects the atmosphere of joy and value pick.

\subsubsection{Side compound}

This compound is located on the right and left side of a traditional Malay houses. The space functions as a space routes connecting the front and rear compound. Depending on the overall land size of the owner house, this compound is also a play area for children.

\subsubsection{Rear compound}

The rear compound of Malay traditional house is a space that connects the kitchen activities of traditional Malay houses such as bathing, washing and cooking. This space is 
the space activities of colloquial done. Sometimes, this space is used by the women to gather during feasts and other social activities.

\subsection{Desa Wawasan concept}

Gerakan Desa Wawasan is the process of raising awareness and development of the attitude of villagers towards rural transformation. This movement or concept emphasizes the involvement of village residents in the planning of development programs towards achieving a more developed village, attractive and profitable. The main goal of Gerakan Desa Wawasan (GDW) is to create a sustainable rural communities, independent, knowledgeable and have high work discipline to implement the modernization of the countryside. Through GDW plans also being made to expand the capacity of villagers to form village scenario of 2020. Various programs were implemented under this GDW, example Human and Awareness Building Programme, Village Inspiration, Home stay Program and the Environmental Beautification Program.

\section{0 Methodology}

\subsection{Research design}

Research on the landscape design for Malay contemporary house at Desa Wawasan is carried out qualitatively. This refers to the need and ability to obtain data and information for the needs of the study. The research has been conducted to see the design or layout of the external environment that commonly found in rural Malay community of contemporary house. It seeks to identify the phenomenon and design pattern of the external environment of typical Malay society. In addition, the collection of information is also made based on readings from secondary sources for research writing. Method of reading is important to avoid any duplication of opinion and fact and in common with previous research.

\subsection{Scope of the study}

This research has set the scope for the house surrounding of contemporary Malay society in Desa Wawasan. In addition, some villages along Sungai Perak edge with high traditional values but are not left behind in modernization has been selected to give responses which regards to the diversity of landscape design of Malay house society. Among the villages selected include Kampung Padang Changkat and Kampung Sayong in Kuala Kangsar, other than Kampung Ekor in Bota. These villages are selected based on its privileges as Desa Wawasan, other than to meet the criteria for sampling with the purpose of incriminating residential criteria with landscape as the main subject.

\subsection{Quantitative method}


In general, a total of 60 purposive sampling of residential houses has been selected in the vicinity of Perak. It aims to look at the layout and design patterns on the use of external spaces or environment of a residential of Malay community. The sample details are as follows:

Selected Villages

Kampung Padang Changkat, Kuala Kangsar

Kampung Sayong, Kuala Kangsar

Kampung Ekor, Bota

3 villages
Respondent

20

20

20

60 set of respondents

Figure 1: List of study sample

\subsection{Qualitative method}

Qualitative data comprises secondary data sources, field study and interview method. Details of information available to state an opinion or personal view with regards to something. In addition, information that is based on secondary sources such as literature, the stories of ancestors as well as photographs, are related. The following is the method of information gathering undertaken in this study.

\subsection{Analysis and Discussion Review}

The results obtained in the study of Landscape Design for Malay Contemporary House at Desa Wawasan in this vision has helped to get the real picture of the pattern for the current residential landscape for Malay community. It also highlights a number of ancillary issues related to the role and function of a landscape. Among others, this study was able to garner a number of problems that tend to influence in the landscape design.

\subsection{Polar for landscape design for Malay contemporary house}

Research findings that has been conducted at a few areas in the vicinity of Perak has been given an overview of common elements or is likely to be used by typical Malay community in creating landscape design at their house compound. These common elements can then be used as a basis for identifying a residential landscape design that reflects the current residential of Malay society.

Based on the results obtained, it is stated that although the Malay society nowadays is accepting the various external influences that shape the lives of today, in fact, this community has still not set aside some cultural aspects that are held indirectly. Cultural aspects that have been preserved does not cover all the past traditional civilizations. These superstitious elements are no longer getting attention in the local community. In fact, the mentality of society is more open and more to meet current demands. 


\subsection{Space requirements and typical activities of landscape setting at Malay contemporary house}

Space requirements and activities in the compound of Malay house is based on the results of the study where by the tendency of an element is placed in a column based on a function or activity.

Research findings through observation method has identified that the distribution pattern of landscape for all the residential sample shows some tendency equation or similarities that construed as a common characteristic or typical.

Generally, the distribution obtained is still not synonymous with the distribution of landscape tradition. This may be due to the nature of mentality and the tendency of a nation that's difficult to delete from their lives. This aspect particularly touches on the habits of Malay society who are more concerned about the interpretation or perception of outsider regarding their personal or their house landscape as compared to interests of their own (Bunnell T, 2002). This situation can be first seen at the placement of wide compound in front of the house. Then, at this compound, it will be planted with ornamental plants that can capture interests in order to attract attention and give comfort to the visitors. Hence, ornamental plants play a greater role especially in the front and side house compound as compare to the of rear space which is more hidden. Apart of providing a huge compound in front of the house, decoration and attractive as a guest attraction, home of Malay society has often had the space at one side of their house where by it stand as a place of assembly or doing some activity. This area is also the area to perform certain functions such as weddings, associations and so forth.

The perception or the mentality that led to the actions of any society, especially the Malay community in the context of beautification meet the findings of this study. This was even said to be true and cannot be blamed since the results derived from the fact that it can be concluded that a conclusion of any action done with the grounds and reasons of its own. But this reason can meet the goal of research in studying and identifying the distribution of a landscape design for the Malay contemporary house design vision in several villages.

Therefore, it can be concluded from the materials obtained, among others, that Malays tend to present common practice in traditional cultural practices while receiving a variety of external influences. However, the practice is not too fanatic and especially in view of the tendency of ornamental plant selection as a special element to a garden show how the community will have shifted their paradigm to receive development and technological progress as various efforts to obtain satisfaction of the acceptance of society as a whole.

\subsection{Typical elements in landscape of Malay house contemporary}

\subsubsection{Soft landscape elements}

Soft landscape elements are known as the landscape elements that represent nature. It consists of a variety of species of plants from various categories or types. The study found 


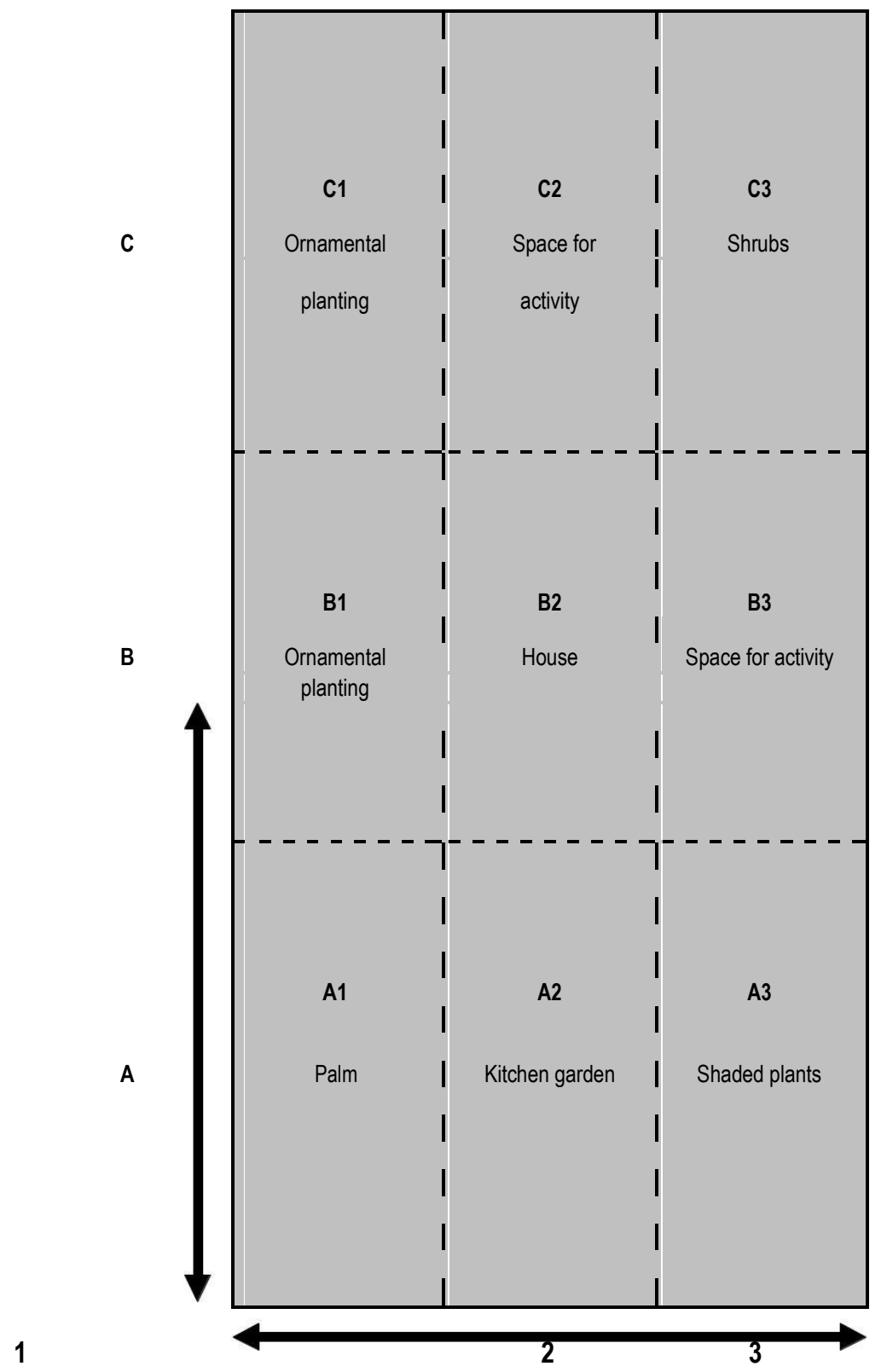

Figure 2: Distribution of common elements of landscape setting at Malay house contemporary 
that soft landscape elements that usually have a high tendency used as the compound decorations for Malay contemporary house compound which varies from the ornamental plants, herbs / kitchen garden, shaded plants and palm. In addition, other plant categories are also planted is water plants, climbing plants, orchid plants, exotic plants and seasonal plants. However, these plants does not meet the criteria selection of respondents as a common landscape element.

In the context of ornamental plants as in this study, it comprises of shrub, groundcovers and also exotic plant. For most respondents, ornamental plants termed as plants with good benefits in terms of it's colour, smell, shape, size and interest. Ornamental plants also include plants that are grown on the ground, plants in pots, hanging plants as well as water plants. Herbal plants / kitchen garden is grouped as the edible plants which have much usage rather than for decorative purposes as well as for food. These plants are usually planted based on past usage, example like betel leaf, dukung anak, gelenggang and others. Other than that, edible plants also included plants that were grown for the purpose of cooking or food sources such as vegetables, fruits and salads, or know as the herbs/kitchen garden plants. This is because these plants are usually planted near the kitchen of the Malay house community.

In addition, shaded plants are plants that are known as trees which can be categorised as big tree 'overstory trees' or the category of medium trees' understory trees. These trees serve as shade where by the spreading root system acting as anchor or provide support to the area. Among other things, large trees that often found are fruit trees like durian trees, rambutan trees and mango trees, other than beringin, ketapang, and hujan-hujan which also become the favourite plants planted by the Malay society. They will then design the rest area, such as benches, a swing and camp as a place to rest, and during group activities and so forth.

Palm is already synonymous to the life of the villagers. Palm is the easiest plant species that can be classified as the family of palmae. The tradition civilization reflect palm as to demarcate boundary as well as to demarcate birth for each new born baby. While the use of betel palm as part of the custom of eating betel leave also prove that this plant plays a big role in the Malay community for the past centuries. Thus, it cannot be denied that this plant is more easily adapted in a landscape design of Malay community.

\subsubsection{Hard landscape elements}

In the context of landscape, hard landscape can be categories as the man-made elements. It is the design of an additional element that complements the design of a landscape garden.

Based on the site observation, it is found that the current society prefer to use hard landscape as the attractive component to their landscapes setting. Among the hard landscape elements that commonly used in the landscape of Malay contemporary society including gazebo as a place to meet, pergola, concrete pots, water features, fountains, swings and park benches. 
Lighting also plays an role in the landscape setting, especially for supplying enough capacity of light during night time. This is not only giving comfort to the residents but also alarm from any possiblity danger. The usage of garden lights, lamps, LED light were found to have a high tendency utilized by the community, especially during the festive season. Furthermore, the use of these elements will increase the benefits and beauty of a site specifically for the residential of Malay contemporary community.

\section{0 Conclusion}

The results of the study, review of aspects of the identity of the landscape for the Malay community as refer back to the study done at several rural villages have identified that the cultural tradition or civilization has not set aside in daily life of the Malay society. Although in general, the perception and the mentality of society increasingly colonized, but in principle, the tradition and culture is still the remains and close to heart of the society, especially to the Malay community. Thus, cultural factors may be considered in designing an image or identity of landscape characteristics of a society.

The role played by Desa Wawasan for example is so helpful in enhancing the effectiveness of a plan, especially in the context of designing landscape. Activities and aspirations from this concept is clearly to be seen more effective and efficient with effort could be applied to stimulate the involvement of a large number of local people. Extensive involvement is more comprehensive and practical to maintain the continuity and survival of habit and civilization that can be a culture which can pass through can carried forward for future generation.

Hence, the findings showed the tendency of people to recognize and accept landscape activities as a complement or a need for a better environment from a small scope or even covering all areas within a city, for example. Landscape flourish although still new and uncertain in determining their own identity, however, cultural factors, preferences, and the planning of GDW can be considered in carrying out a study to forming or shaping a nation's identity, especially in the context of landscape contemporary. Among other things, contemporary approach that is used as a platform in the development realize between two different times, both traditional as well as for interactive development in the future. Thus, contemporary studies also able to highlight the elements of tradition that is considered 'Evergreen' to be introduced in the future, or at least not be set aside as a reflection of the traditions that make this nation grow and successful to this day.

\section{Acknowledgement}

Our heartiest gratitude to Universiti Teknologi MARA (UiTM) for the financial assistance in funding the research. 


\section{References}

Abdul, R.E. (2000). Negara Pasaran dan Pemodenan Malaysia. Bangi: Penerbit Universiti Kebangsaan (UKM). Ali, S.H. (1979). Orang Melayu: Masalah \& Masa depannya. K.Lumpur: Penerbitan Adabi Sdn. Bhd.

Asmad. (1990). Seni Kehidupan dan Kemasyarakatan. Kuala Lumpur: Cetaktama Sdn. Bhd.

Asnarulkhadi, A.S. and Jawan A. (1997). Kenegaraan Malaysia. Serdang: Penerbit Universiti Putra (UPM)

Bell, S. (1993). Elements of Visual Design in the Landscape. London: E \& FN Spon, An Imprint of Chapman \& Hall.

Booth, N.K, ASLA (1991). Residential Landscape Architecture: Design Process for The Private Residence. New Jersey: Pearson Education Inc.

Bunnel, T. (2002). Kampung Rules: Landscape and the Contested Government of the Urban(e) Malayness, Journal of Urban Studies, 39 (9), 1685-1701, February 2002

Eckbo, G. (1978). Home Landscape; The Art of Home Landscaping. United States of America: Halliday Lithograph Corporation.

Ismail, N.A. and Said. I. (2002). "Design Paradigm: Sustaining Responsive Cultural Landscape of Malay Rural Residential Area". Proceeding of Second International Seminar on Vernacular Settlement. 316-323.

Julaihi Wahid. (2003). Globalisasi, Modernisme dan Aliran Arsitektur Nusantara - Dimana Kita ?; Simposium Jelajah Arsitektur Nusantara, Brastagi, Medan, Indonesia; 11 - 14 Disember 2003.

Koharuddin, M.B. (2005). Pembangunan Luar Bandar di Malaysia: Gerakan Desa Wawasan (GWD) sebagai Mekanisme Pembangunan Masyarakat Luar Bandar. Universiti Teknologi Malaysia.

Laurie, M. (1986). An Introduction to Landcsape Architecture. New York: Elsevier Science Publishing Co. Inc.

Lecte, J. (2001). 50 Filsuf Kontemporer, Dari Strukturalisme Sampai Postmodernitas. Yogyakarta, Indonesia: Penerbit Kanisius.

Lim, JY. (1997). The Malay House: Rediscovering Malaysia's Indigenous Shelter System. Institut Masyarakat, Malaysia.

Maliki, N.Z. (2008). "Kampung / landscape: rural-urban migrants' interpretations of their home landscape. The case of Alor Star and Kuala Lumpur". Phd Thesis. Lincoln University, NZ

McHarg, IL. (1967). Design With Nature. New York: John Wiley \& Sons, Inc.

Nasir, A.H. and Wan Teh, W.H. (1997). Warisan Senibina Melayu. Bangi: Penerbit Universiti Kebangsaan Malaysia.

Osman, M.T. and Yusoff, W.K. (1983). Kajian Budaya dan Masyarakat di Malaysia. Kuala Lumpur: Dewan Bahasa dan Pustaka. 
Mohd Hussein, N.H., \& Ahmad, S. / Asian Journal of Environmen-Behaviour Studies, ajE-Bs, 2(2) Jan / Mar 2017 (p.93-103)

Yahya, M.A. (1995). Simbolisme dalam Senibina Rumah Melayu. Kuala Lumpur: DBP. Zube, E.H. (1975). Landscape Assessment: Values, Perceptions, and Resources.

Stroudsburg, Pennsylvania: Dowden, Hutchingson \& Ross, Inc. 